\title{
Reconstructing the good farmer identity: shifts in farmer identities and farm management practices to improve water quality
}

\author{
Jean McGuire • Lois Wright Morton • \\ Alicia D. Cast
}

Accepted: 5 April 2012/Published online: 20 June 2012

(c) The Author(s) 2012. This article is published with open access at Springerlink.com

\begin{abstract}
All farmers have their own version of what it means to be a good farmer. For many US farmers a large portion of their identity is defined by the high input, high output production systems they manage to produce food, fiber or fuel. However, the unintended consequences of highly productivist systems are often increased soil erosion and the pollution of ground and surface water. A large number of farmers have conservationist identities within their good farmer identity, however their conservation goals often need to be activated to rebalance the production-conservation meanings they give to their roles in society. In this paper we analyze US Cornbelt farmer interviews and surveys to trace how the performance-based environmental management process can be used to influence the farmer social identity and shift the overall good farmer identity towards a stronger conservationist standard. We find the continuous feedback loop in performancebased environmental management mimics the hierarchically organized feedback control processes of identity verification and can be used to help farmers activate their conservationist farmer identities at the person, role, and social levels to establish new norms for the practice of more sustainable agriculture.
\end{abstract}

J. McGuire $(\bowtie) \cdot$ L. W. Morton

Department of Sociology, Iowa State University,

317 East Hall, Ames, IA 50011, USA

e-mail: jmcguire@iastate.edu

\section{A. D. Cast}

Department of Sociology, University of California,

3133 Social Sciences and Media Studies Building,

Santa Barbara, CA 93106, USA
Keywords Productivist - Conservationist . Farmer identity · Water quality · Performance-based management $\cdot$ Farmer decision-making

\section{Introduction}

US public opinion research shows that most Americans feel that agriculture has caused "significant environmental problems" (Harris and Bailey 2002, p. 34). Harris and Bailey report that agrichemical companies, the government, and consumers are seen by the general public as bearing some of the responsibility for the pollution problems caused by US agricultural production. However, the public identifies farmers as having the most direct role in causing environmental damage (Harris and Bailey 2002). Thus, farmers, who are viewed as essential to food production are now also perceived as business persons who are likely to disregard environmental impacts of their decisions and place personal profit before public welfare. Tensions between agricultural production and environmental goals of the farmer role in society permeate media, public agency efforts to increase adoption of conservation practices, and public conversations (Brasher 2011; Elworth 2011).

Although there is a renewed recognition that agriculture serves multiple functions including the production of food and fuel as well as ecosystem services (Schulte et al. 2010; Wortmann et al. 2005), there is a body of literature that suggests the productivist identity dominates the decision making process thereby putting water quality and other environmental goals at risk (Burton 2004; Burton and Wilson 2006; Chouinard et al. 2008; Herndl et al. 2011; NRC (National Research Council) 2010). Soil erosion and leaching of agricultural nutrients off-field into proximate water bodies continues to be a persistent and significant 
source of gulf and bay hypoxia ${ }^{1}$ (US EPA 2009). This suggests that the conservation and productivist roles are out-of-balance for many farmers. Addressing water quality problems that are the result of agricultural practices requires that farmers recognize they have an important role in protecting the environment thereby activating their sense of conservation responsibility.

Despite recognition that systems of agriculture have changed significantly over the last 50 years (NRC (National Research Council) 2010; Pretty 1995), there is much we do not understand about how farmers perceive their role (their "farmer identity") and make trade-off decisions between farm profits and conservation goals (Burton and Paragahawewa 2011; Chouinard et al. 2008; NRC (National Research Council) 2010; Reimer et al. 2012; Schneider et al. 2010; Sutherland and Burton 2011; Wilson 2004). A farmer's person, role, and social identities are complex, dynamic, and often context specific. In this paper we explore the identities of a group of Iowa farmers who not only manage productive, profitable farms but also are keenly aware of water quality issues and their responsibility to address these concerns. Others have examined what factors contribute to a farmer's adoption of stronger environmental stewardship identities that moderate the power of the profitability identity (Genskow 2012; Lemke et al. 2010; Lockie 1998; Sheeder and Lynne 2011). Our work specifically seeks to understand the mechanisms within a farmer's identity structure that allow him/her to balance the conflict between protecting the environment and producing high yields and profits in the production of corn and soybean. First, farmer management for production and conservation goals and the connection to farmer identity are presented. Then the identity framework is used to analyze how the information and social connection feedback loops of the performance-based environmental management process change farmer identities and behaviors. Next, research methodology and data collection processes are discussed followed by findings. Lastly, conclusions, implications, and research limitations are presented.

\section{Managing for production and water quality}

The rural landscape in the United States (US) has been dramatically altered by "high-input, high-output (HIHO) agriculture" (Pretty 1995, pp. 29-30). High-input, highoutput agriculture follows an industrial model of production, using intensive applications of fertilizers and other

\footnotetext{
${ }^{1}$ Hypoxia is the result of excess nitrogen and phosphorus which stimulate algae growth and as a result block sunlight to underwater plants. Algae consumes oxygen during growth and decomposition stages reducing oxygen availability for other aquatic life (US EPA 2009).
}

chemicals, extensive mono-cropped acreages which are planted, tilled, and harvested by large high tech equipment, and concentrated animal feeding operations which are space and labor efficient and feed intensive. The dominant US farmer identity is based in this production system and the ability to achieve higher and higher yields per acre, produce more chickens, cattle, and hogs per square foot, and the continuous adoption of new technologies to produce more food, fiber, and feed (Herndl et al. 2011). Since the 1990s this system of production has added bioeconomy goals as agriculture seeks to become a major source of renewable energy (NRC (National Research Council) 2010; Pelkmans 2005).

The unintended environmental effects of HIHO agriculture include increased loss of soil, reduced biodiversity, and degradation of water resources. The United States Environmental Protection Agency (US EPA) estimates that US agricultural landscapes are the largest source of water impairments (excess nitrogen, phosphorus, and sediment) affecting nearly half of all polluted streams and rivers. In addition, agricultural pollutants are the source of more than $45 \%$ of damage to lakes and $18 \%$ of damage to estuaries (Ribaudo and Johansson 2006) with increases in nitrogen compounds primarily from agricultural fertilizers upsetting the natural nitrogen balances (Ribaudo 2011). Due to its diffuse nature, agricultural nonpoint source pollution (NPS) is difficult to measure, monitor, and reduce. However, the widespread growth of hypoxic zones, areas in water bodies with low oxygen, in the Gulf of Mexico, the Chesapeake Bay, and other bays and river outlets throughout the US demonstrate agriculture's impact on water (Ribaudo 2011; Ribaudo and Johansson 2006). This has led to a new urgency and greater political will to identify NPS sources and attempt to control excessive phosphorus, nitrogen, and sediment loss from upstream agricultural production systems.

Some farmers recognize that they need to do a better job of reducing the negative impacts of their farm practices on the environment (Arbuckle et al. 2009; Boonstra et al. 2011; Pfeffer and Wagenet 2011; Selfa and Becerra 2011). However, although crop productivity continues to increase, there are many farmers who are not actively managing to keep nitrogen and other nutrients on their fields and out of neighboring water bodies. Ribaudo (2011) reports that only $35 \%$ of US croplands are being managed to meet the three criteria (rate, timing, and method) for good nitrogen management.

Efforts to understand what factors farmers consider when making farm management decisions and why conservation practices are not widely adopted have generated a great deal of literature in the past few decades. Prior to mid-1980s, much of the social science literature on farmer decision making applied the economic rational actor 
(Simon 1955), the theory of planned behavior (Ajzen and Fishbein 1980), and adoption and diffusion (Bohlen and Beal 1957; Rogers 1983) to explain behaviors. More recently, a meta-analysis of 55 articles addressing the adoption of agricultural best management practices (BMP) report that no socio-demographic factors consistently determined BMP adoption (Prokopy et al. 2008). However, a number of social and belief and attitude variables significantly influence adoption of conservation management practices: access to information, awareness, social networks, positive attitudes about environmental quality, and attitudes toward risk (Campbell et al. 2011; Floress et al. 2011; Lokhorst et al. 2010; Prokopy et al. 2008). In other work, Coughenour (2003) found that exposure to new relationships, ideas, and technologies can lead to the reconstruction of current mental conceptions about how the world works, new identities as conservationist farmers, and adoption of conservation management practices.

Efforts to classify farmer internal motives for adopting (or not) conservation practices reveal a number of factors (production, stewardship, lifestyle, social benefits, land, institutional barriers), with many studies reporting economic and conservation concepts dominating findings (Chouinard et al. 2008; Dobbs and Pretty 2004; Maybery et al. 2005). The dual interests framework featured in economics literature by Lynne (2006) and others (Bishop et al. 2010; Chouinard et al. 2008; Lynne and Rola 1988; Lynne et al. 1988; Sheeder and Lynne 2011) proposes that farmers are motivated not just to act in ways that produce the best economic results but are also motivated by personal beliefs and attitudes about how farming should be practiced. Lynne (2006) finds that this dual interest or multi-utility framework explains the economic profitability-conservation trade-offs that occur as farmers make management decisions. The simultaneous presence of economics as reason-based and conservation values as affect-based is supported by Slovic's (2009) findings that decision making is a combination of affect heuristics and reason-based analysis.

In many ways multi-utility frameworks are consistent with social psychological theories of identity. Within the discipline of sociology, Stryker and Burke (2000) and others (Burke and Stets 2009; Stets and Carter 2011) have developed what is referred to as identity theory. This theoretical perspective suggests that individuals' self-meanings drive how individuals act. Identity theory does not assume specific characteristics such as self-interest but rather proposes that each individual holds "... a set of meanings that define who one is when one is an occupant of a particular role in society, a member of a particular group, or claims particular characteristics that identify him or her as a unique person" (Burke and Stets 2009, p. 3). In a very general sense, behavior is how an individual expresses his/her identity as a person, in a particular role and/or social setting (Burke 1997; Heise 1979; Stets 1997; Stryker and Burke 2000). Thus, individuals have multiple identities, based on their social networks and the positions they occupy in each setting (Burke and Stets 2009), which may be activated by the social context. These identities reflect individuals' positioning within the social structure and set the standards for how an individual will act (Stets and Burke 2000).

Of interest to the research presented here is the farmer role in society and, as a member of a particular group, how the farmer constructs and re-constructs his/her identities, and how these identities influence profitability and conservation behaviors. The identity control model (Burke 1991), when connected to an intervention such as the performance-based environmental management process, illustrates how identity theory can be used to activate and incentivize farmer management values and the adoption of conservation approaches that ultimately rebalance single focused, self-interested economic behaviors.

\section{Identity theory, the good farmer identity, and performance-based environmental management}

A person identity is comprised of "the set of meanings that are tied to and sustain the individual" (Stets 2006, p. 90). These meanings serve as a standard or reference for the identity. Person identities reflect individuals' understandings of themselves as having particular traits and qualities. Because of this, they tend to be relevant across roles and within a variety of situations making them quite high in an individual's identity salience hierarchy (Stets 2006). The salience hierarchy is determined by the opportunities that an individual has to enact their various identities. The more likely a person is to enact a particular identity on a regular basis, the higher it is in the hierarchy (Stryker 1980). Since a more salient identity is likely to be activated more often, it becomes possible to predict how a person may act in specific situations (Burke and Stets 2009). The person identity is often considered the organizer and modifier of a person's role and social (group) identities (Burke 2004); in this sense, it can be thought of as a master identity. Like other identities, the person identity is maintained by a feedback process that checks the social environment to see what kind of responses (reflected appraisals) a person's actions are generating and, if needed, adjusts their behavior or identity standards (Stets and Burke 2003).

The feedback loop shown in Fig. 1 demonstrates how this system operates. The four nodes (Comparator, Output, Social Situation, Input) operate as a system that is constantly checking to see if a person's actions are producing the desired effect (Burke 1991). Inputs into the system are 


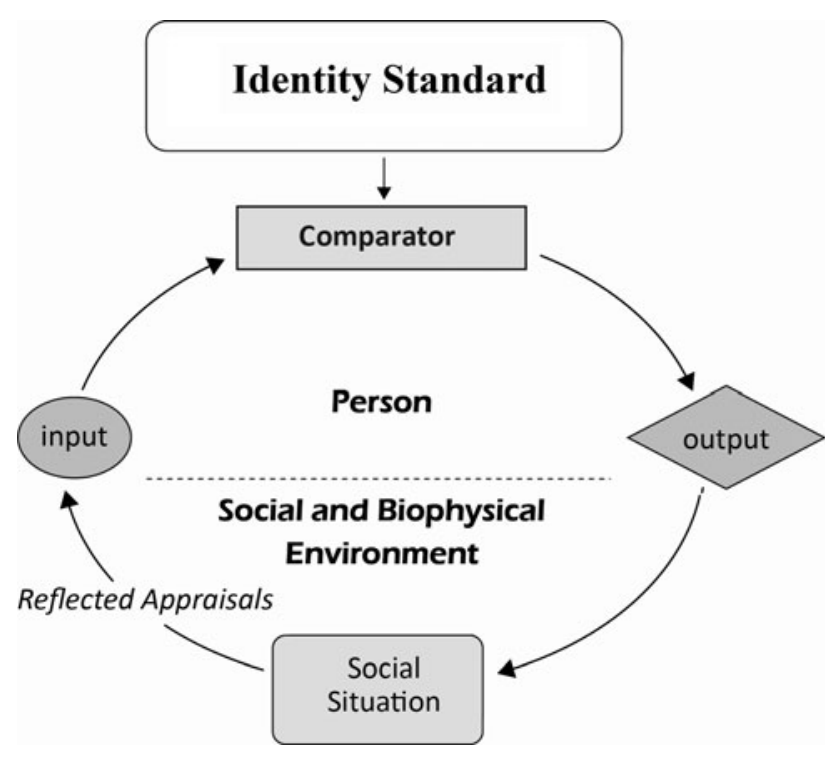

Fig. 1 Identity control model. Source: Adapted from Burke (1991, p. 838)

compared to identity standards. When a person acts (output) in a particular situation, the environment (social and biophysical) provides feedback (input). If the feedback supports or "matches" the identity standard, the identity is verified. If the feedback (input) is inconsistent with the identity standard, the individual can change his/her behavior (output) in an attempt to alter situational meanings so that they become consistent with the identity standard or alter their identity standard to become consistent with the situational inputs.

A role identity operates similarly to the person identity, however, a role identity "includes all of the meanings that a person attaches to himself while performing that role" (Stets 2006, p. 89). Role identities are verified through the same feedback control process outlined above. Identities do not exist in isolation, however. They are arranged in a hierarchy of nested identities with a particular identity at the top interconnected to other identities at lower levels. Furthermore, standards within each identity vary in terms of their relative abstractness. Higher-level standards are principle-level standards that are typically abstract. The principle-level is supported by more specific, concrete standards and goals known as program-level standards. Each identity and the associated feedback loops within the hierarchy have multiple input meanings and require verification simultaneously when activated. Each action (output) that an individual performs is in support of one or more of their identities (Tsushima and Burke 1999).

Applied to our research, each farmer has an abstract principle-level set of standards that define what makes a good farmer ("steward of the land") and multiple lower program-level standards which relate to specific concrete goals and behaviors in support of their overall self-definition ("correct use of pesticides"). The diagram in Fig. 2 offers a simplified example: the principle-level identity standard (comparator A "I am a good farmer") is supported by two sets of identity standards: productivist (comparator B) and conservationist (comparator C) which have differing outputs. The outputs from comparator B and comparator $\mathrm{C}$ are processed simultaneously within a specific social situation. Perceptions within the social situation (the farmer's perceptions of how well he/she is meeting the standards set within the identity) feed back into comparator $\mathrm{B}$ and comparator $\mathrm{C}$ and are verified (if the meanings in the situation "match" the identity standards), adjusted, or disregarded. Supporting the productivist standard are multiple lower level identity standards in the hierarchy (not shown) with increasingly more concrete standards and goals (e.g., standards about weed free fields, yield standards). Similarly, supporting the conservationist standards are more concrete lower level program standards that have feedback loops that alter the inputs into those higher level control systems (e.g., standards about soil erosion, loss of nitrogen from in-field management).

The functioning of the farmer identity is highly complex with the control systems at these various abstract and concrete levels continually working to assess whether the feedback from the social environment is consistent with the meanings that define for a farmer what a good farmer is. Interaction and adjustment of identity standards among these layers are how individuals maintain or change their identities depending on the feedback from the social/ physical environment (Burke 2006). This process can happen slowly through everyday interactions over a long period of time, or may change rapidly as the result of a single negative or positive event outside of a person's control (Burke 2006).

Burton (2004) also applied a general theory of identity to the British grain farmer. He found that a strong relationship existed among the farmers' person, role, and group identities, prompting him to propose the concept, "the good farmer identity." He identified four key sub-identity standards from which the good farmer role identity was built: (1) physical appearance of the crop and/or livestock; (2) crop yield per hectare or other similar measures of production; (3) "Hedgerow farming" which is the comparison and evaluation process of how well farmers in specific geographic areas are meeting the local, informal, farming standards; and (4) the "farm" identity which represents the farm's physical characteristics as well as the family farming the land and the history of the farm (Burton 2004; Sitko 2007).

Later Burton and Wilson (2006) developed a typology to describe how these multiple identities were organized in a hierarchy with the most important identity as the most 
Fig. 2 Good farmer identity control model. Source: Adapted from Burke and Stets (2009, p. 134)

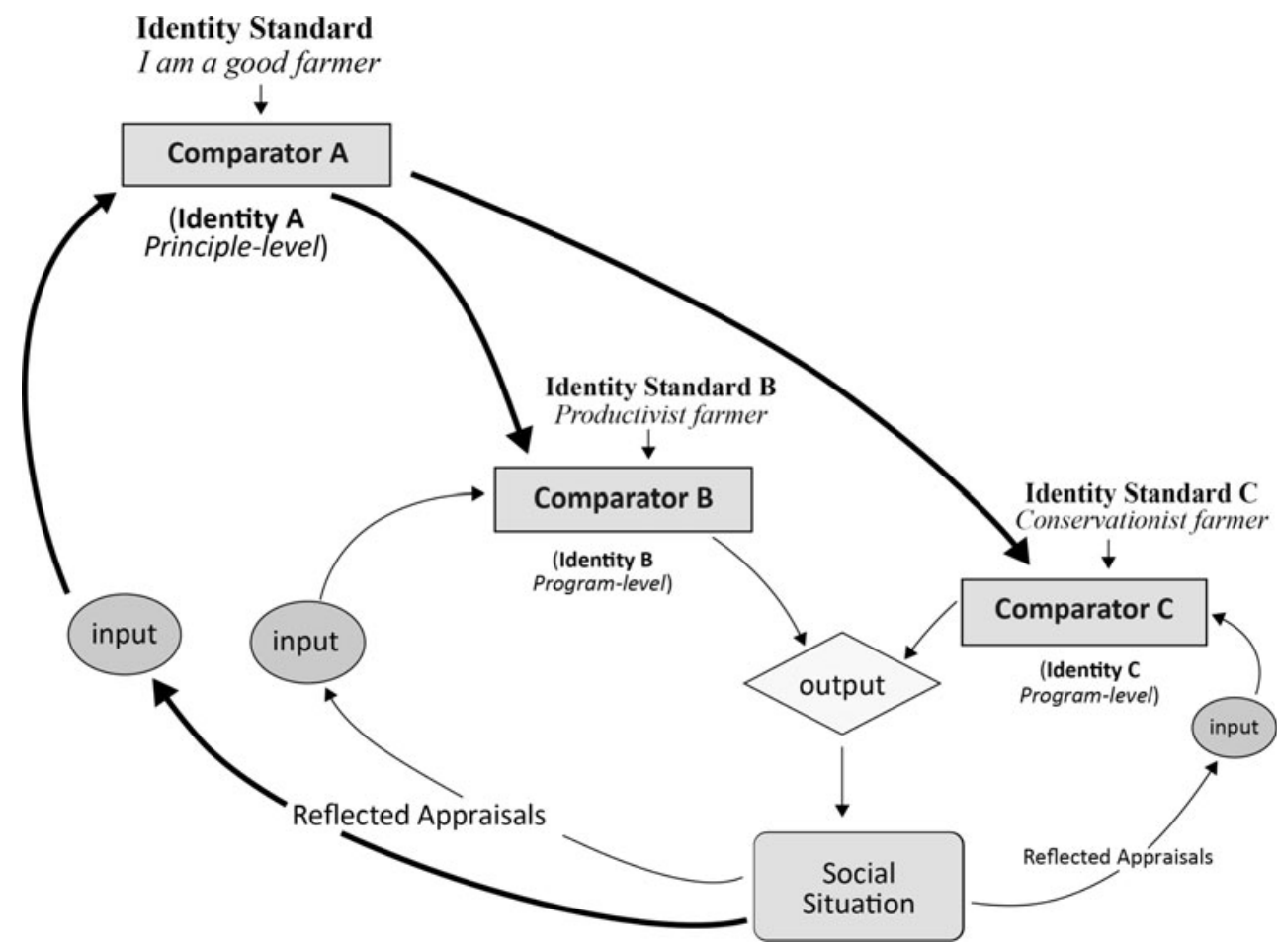

influential. The predominant farmer identity category was the agricultural productivist/agribusiness group (Burton and Wilson 2006). Seventy-eight percent of the farmers described themselves as farmers who rely on improved yields, land acquisition, and improved operational efficiencies as the way to increase income thereby demonstrating their good farmer identity (Burton and Wilson 2006). The second category was diversifier. Thirteen percent of the farmers described themselves as farmers who use their farm to help them create what is known in US agriculture as value-added agriculture. The final category, conservationist, described just $8 \%$ of the British farmers. These farmers took an environmental manager approach when planning and implementing farm management practices and managed their land as something more than a tool to create high yields and income. Even though they grew commodities and adopted agriculture producer/agribusiness farming methods, they also used practices that produced ecosystem services-clean water, habitat for wildlife, and soil conservation. Thus, input standards of high yield and income were balanced with input standards of esthetic and environmental concerns (Burton and Wilson 2006).

Lastly, a social identity reflects how “... people categorize themselves as similar to some, labeled the in-group, and different from others, the out-group" (Stets 2006, p. 89). Social identities give individuals a chance to feel they are part of something bigger than themselves. When an individual is able to link their role and person identities with an abstract group identity, that individual more completely connects to that group identity than they would if their role and person identities are not as closely linked to the group identity (Burke and Stets 2000). A social identity can be as broad as being a citizen of the United States or as specific as being a member of a group of siblings. The farmers described in this research have developed a social identity of being farmers within a specific watershed.

A farmer's social identity standard is re-affirmed or revised based on input from in-group interactions and relationships and input from external groups (out-group) within a specific social situation. This social identity in turn becomes the feedback input that affirms, or recommends a revision to, the current person and farmer role identities. One strategy to incentivize or encourage a conservation identity standard in the good farmer role identity is to utilize the group effect that naturally occurs in the development of and revisions to identity standards. For this to happen reflected appraisals and perceived self-meanings of the social situation must provide input that managing water quality impacts is important to the group and within group comparisons of actions and meanings must lead to the development of a revised identity standard. Thus, the "Social Situation" in the Identity Control Model (Fig. 1) is where an education intervention holds potential.

In this research we utilize the performance-based environmental management process as an educational intervention to trace the development of stronger environmental stewardship identities over time. We examine the capacity of the social identity standard of an in-group to shift good 
farmer role identities from a productivist, profitability selfinterest to a shared-other interest as reflected in their willingness to adopt conservation practices to protect the water quality of their local watershed.

Performance assessment has been used extensively in manufacturing and service-based industries as a feedback mechanism to meet safety and environmental regulations and to improve manufacturing processes (Lokhorst et al. 2010; Wilson and Pearson 1995). Iowa State University (ISU) Extension introduced the concept to farmer-led watershed groups and applied it to managing agricultural systems for environmental outcomes (Morton et al. 2006). This six-step continuous improvement process is a tool farmers can use to monitor land use practices and potential nitrogen and phosphorous leakage and sediment loss at the farm and watershed levels (Morton and Weng 2009). Performance-based environmental management is an information feedback loop (awareness, assessment, set goals and make plans, target water and soil issue, track and evaluate performance, and modify practices) that enables farmers to individually and as a group track and measure environmental impacts at field, farm, and watershed levels in order to modify management decisions as a result of what they learned. We posit that in the process of modifying management decisions, the social, role, and person identities of these farmers also shift, and stronger conservation standards are incorporated into their identities.

\section{Methods}

Data to illustrate how the performance-based environmental management intervention creates a new social situation and influences farmer identities and actions are drawn from (1) a case study of one of the NE Iowa farmerled groups using in-depth, panel interviews with nine participating farmers and (2) 83 pre (2005-2006) and 50 post (2009) assessment surveys of three farmer-led $\mathrm{HUC}^{2}{ }^{2}$ watershed groups in NE Iowa using the performance-based management process. Between the pre and post surveys, Extension watershed technical specialists helped watershed farmers learn how to use three performance tools to track pollutants: the Iowa Phosphorus Index (P-Index), ${ }^{3}$

\footnotetext{
2 The US Geological Survey (USGS) developed a hierarchical hydrologic unit code (HUC) system for the United States. A HUC defines the boundaries of surface water drainage to a specific point. HUC 12 level is considered the subwatershed level and typically covers an area of 10,000-40,000 acres (NRCS 2010).

3 The Iowa Phosphorus Index (P-Index) is a risk assessment tool for assessing the potential of phosphorus delivery from fields to surface waters and is used in nutrient management and conservation planning tools by USDA-NRCS.
}

cornstalk nitrate test, ${ }^{4}$ and the Soil Conditioning Index ${ }^{5}$ (SCI). These tools provided farmers feedback data on their own fields and when shared with the entire group in aggregated form provided data to evaluate and discuss the collective impact of their practices to their local watershed.

The data collected from these tests during the first project year (2005-2006) provided farmers and watershed specialists with baseline measurements. Each year, specialists met one-on-one with farmers to explain the test results and suggest a range of farm management practices that could be adopted to improve the scores for each of the tests. Farmers then implemented the practices they thought would best address the water quality issue on their farms and recorded the results each year. Data from participating farmers were compiled by the Extension specialists and shared with the entire farmer watershed group at meetings. A coding system protected the participants' privacy as individual-level and group-level success and failure at reaching watershed goals were discussed. The group discussion process provided the social situation feedback loop, censoring behaviors that harm water quality and rewarding practices that could lead to improved water conditions. We analyze this process to determine the extent to which the social identity standard of the participating farmers shifted over time.

In-person interviews of nine farmers and observational and archival data on the watershed group (media, project reports, and meeting minutes) were collected over a four year period (2005-2008) and used to track how farmers identified themselves and changed their farm management practices. In July 2005, shortly after the first farmer-led watershed group ( $\sim 20$ farmers) formed around their HUC 12 watershed, seven farmers were interviewed (audio recorded) by a graduate student at their farms as well as two ISU Extension watershed technical specialists facilitating the farmer-led group. In 2008, a second round of interviews was conducted by another graduate student with six of the original farmers and three additional farmers and the two watershed technical specialists. The farmers interviewed ranged in age from 34 to 68. Most of those interviewed had livestock operations, primarily dairy, all had been raised in or near the watershed.

Interview questions focused on farmer perceptions of local ground and surface water quality, perceptions of regulators' role in regards to water quality, how they were

\footnotetext{
${ }^{4}$ The cornstalk nitrate test is designed to estimate the amount of nitrogen left in the soil at the end of a crop year. Corn plants that contain more nitrogen than needed to attain maximum yields accumulate nitrate in their lower stalks at the end of the season.

5 The Soil Conditioning Index estimates trends in soil organic matter, which are assumed to be an indicator of soil quality trends. The index was developed from Revised Universal Soil Loss Equation (RUSLE) technology.
} 
using the three performance-based management tools ( $\mathrm{P}$ Index, soil condition index, and the nitrate stalk test), how effective these tools were in guiding decision making and impacts on their local water monitoring results, and what management practices they and other farmers were using to address water quality. The interviews were transcribed and independently coded by the authors to identify themes and then reconciled to reduce coding bias. The primary themes that emerged were (1) farmers who collected on-farm data using the three performance tools thought they provided valuable feedback information to improve farm management practices; (2) farmers who made management changes because of feedback believed they had improved water quality as well as improved yield and profitability; (3) various group members who tried different management techniques provided learning opportunities for all group members; (4) farmers developed a sense of collective ownership of the watershed problems; (5) and farmers exhibited pride in being part of the group whose actions led to better water quality. All farmers interviewed were members of the locally led watershed group. There were approximately 83 farmers in the watershed and by 2008 two-thirds (57) of those farmers had participated in the group. Except where noted, the quotes that follow were taken from these interviews.

To verify our case study findings, we also compare pre (2005-2006) and post (2009) assessment surveys of three farmer-led HUC 12 watershed groups in NE Iowa $(83,60$, and 72 farmers in each watershed) using the performancebased management process. Farmer ages in these watersheds ranged from 34 to 93 years old (average age 54 years), and they on average owned 260 acres and rented 182 acres. Farms were mixed rowcrop, forage and livestock. The NE Iowa Watershed group where in-person interviews were conducted was one of the three groups surveyed. All three watersheds had been identified by the US EPA as having impaired water bodies that needed intervention. Within months of the formation of each of the three farmer-led watershed groups, a pre-assessment survey was given to all farmers within their watershed (based on plat map listings of addresses) to assess water quality beliefs, current agricultural management practices, and social connections among farmers and groups they interacted with on a regular basis.

The pre-assessment survey in 2005-2006 $(\mathrm{N}=83 ; 39 \%$ return rate) was followed four years later (2009) by a postassessment $(\mathrm{N}=50 ; 24 \%$ return rate) that included preassessment questions and actions taken as a result of being a member of the farmer-led watershed group. ${ }^{6}$ A second type of data gathered by the watershed groups and Extension from

\footnotetext{
${ }^{6}$ The surveys were sent to all farmers in the watershed, thus rates of return primarily reflect those farmers who are actively engaged in the watershed group.
}

2005 to 2008 were indicators of water quality from selected stream monitoring sites and farm management measures. These data included selected stream water measures for phosphorous, nitrogen, bank erosion and benthic macro invertebrate, the number of feet of new waterways installed, the reduction of nitrogen applied to farm fields, the adoption of various soil conservation practices that reduced soil erosion, and crop yields. In addition to performance-based management tools (P-index, SCI, and Stalk N tests), these indicators of water conditions and productivity were discussed by the watershed groups to understand how the adoption of specific farm management practices could affect land and water biological and chemical outcomes. We use these data to support findings from the case study of one of the farmer-led watershed groups.

\section{Results}

Farmer identities in an Iowa watershed

A watershed is a biophysical phenomenon. However, most of the 83 farmers who live in the NE Iowa Watershed case study site had little knowledge of their watershed and its boundaries until the Iowa Department of Natural Resources (DNR) listed a creek in the watershed as a US EPA 303(d) impaired water body. This designation forced many of the farmers to recognize themselves as agricultural polluters. While the population of farmers in this watershed is fairly stable and appear to share many social, friendship, or kinship relationships, they did not see themselves as responsible for polluting a waterway.

When farmers and landowners learned of the pollution designation, they did not accept this externally ascribed identity. They challenged it by arranging for additional water tests which confirmed that the creek was polluted with excessive amounts of nitrogen, phosphorous, and fecal coliform bacteria. Having the water retested was the first sign that at least some farmers in this watershed were not having their good farmer pro-environment identities verified. Because the pollutants found in the water could not be traced back to any one farm operation, it could be assumed that any and/or all farmer residents in this watershed had in some way contributed to the pollution. Thus, even farmers who used soil and water conservation farm management practices were considered part of the polluter group. In order to address the non-verification of their good farmer identity, these producers could either accept that they were polluters and modify their standard of the good farmer identity to account for the "polluter" portion, or change their behaviors by taking action to reduce the pollution problem thereby allowing them to keep their good farmer identity intact. The tools available to the farmers to address 
the pollution and identity crises were expanded when some of them accepted Extension and researchers' offer to help them form a volunteer-managed watershed group. The creation of this group offered these farmers a way to protect their identity from the outside threat to their autonomy as farmers.

The "crisis" of being branded polluters triggered a chain reaction that resulted in modifications of the locally accepted rules and norms for good farm management. Farmers with strong conservation identity standards responded by adjusting their actions to reflect their existing farmer identity as conservationists and environmentally responsible farmers. As this farmer notes,

When you start getting the DNR involved, then you start getting farmers nervous. By going through this here program [performance-based environmental management], we're trying to improve the watershed without any regulations, basically, so that someday if they say you've got to do this or you've got to do that, we're already making an effort to get there. (Farmer 5, 2005)

When farmers with strong productivist identity standards saw their neighbors with strong conservationist identity standards taking action to protect the water resources, they initiated actions that reaffirmed their less dominant conservation identity, thereby strengthening that identity standard while making it congruent with their productivist identity standard. That is, they modified their productivist identity by adjusting identity standards to align conservationist and agricultural productivist identities and elevated the conservationist identity to a higher level in their identity hierarchy.

\section{Good farmer identity congruence}

Analysis of the 2008 interviews reveals how farmers integrated their productivist and conservationist identities in response to perceptions that their agricultural management practices in 2005 were affecting the water conditions in their local streams. As a result of introducing the performance-based environmental management process (i.e., changing the social situation) farmers' modified their behaviors (outputs) and attempted to control their perceptual input (perceived self-meanings) so that their actions and perceived effects matched their good farmer identity standard. This self-verification led to an increase in conservationist performance to restore perceptions as good farmers and created increased congruence between productivist and conservationist identities and a shift in the good farmer identity standard. One farmer describes how this processed started among the small group of farmers that organized the group:
A bunch of us farmers got together, and we found out that we had high nitrates and fecal in the streams, and we wanted to get it cleaned up. And we started having meetings to figure out how we were going to get the streams cleaned up. One thing led to another, and here we are today, three years later. (Farmer 8, 2008)

However, at first most farmers were not comfortable making changes to locally accepted farm management techniques to include water quality. This farmer with a strong conservationist identity answered early critics by pointing out that performance-based measurements were feedback that would provide a way to achieve production efficiencies and water quality management goals.

You know, they all thought we were nuts, but once you start backing things up with yield data and nitrates, hey, if you want to throw fifty bucks away, go ahead. A thousand dollars a ton for anhydrous[fertilizer]. Well, maybe we can... do something different and it showed. (Farmer 3, 2008)

The decision to change their actions supported local efforts to form a watershed group to improve the quality of the water. Once farmers with strong conservationist identities became involved in the group, they accepted leadership roles and provided support for farmers with strong productivist identities to start to make changes. Here is how one farmer explained the influence they had on each other's behaviors:

We went to the first couple meetings, and then [the extension specialist] stopped numerous times. And I always felt when he stopped there was a reason he was stopping. And I guess we're conservation minded, and we try to do practices that are good for the environment.... You're always hoping you can learn from someone and someone else can learn from you. (Farmer 7, 2008)

The group used the performance-based management model as a process to make changes in their farm management practices in order to address the water quality problems. By adopting this process they started to produce environmental services on their farms in addition to raising livestock and growing crops. One farmer explains how it worked:

I compare this [watershed] to a piece of ground my brother just bought from a farmer south of us. It [the farm] was depleted nutrient-wise big time, and we aren't getting top yields off it. But it's like I told my brother, I said, "We can't change it in two years' time. It's been taking 15 years where it's been depleted." And I kind of, when I think about that farm, I think about [this watershed]. It's the same 
thing_-it didn't happen overnight, and it's not gonna get changed overnight. But if we keep going, keep trying, we'll get things done. (Farmer 7, 2008)

The farmers with strong conservationist identities were not afraid to take chances in order to find ways of keeping their conservation and agricultural producer identities in balance. In some cases, their ideas did not work, but failure did not deter their attempts to verify their good farmer identity. A farmer notes that even though an experiment might fail, it was still a learning opportunity for them:

Well, this was one of our experiments we were trying, so I put 18 acres of no-till rye grass in, in the fall. That's wicked stuff. But [we did] GPS soil samples a year after that. And couldn't believe the kind of organic matter I had on this farm.... What you learn through that experience-rye grass is great for building organic material, but it sucks your nitrogen up terrible on corn. So we had to go back and do some extra side dressing the following year. And that year we took a little ding in the yields, so... we didn't continue that practice. (Farmer 3, 2008)

The following excerpt is from the final report to the funders of this project. In it, the Extension specialist who organized the local group cites an example of how farmers were willing to step up to challenges and how a single farmer's activation of his conservation identity sparked a discussion that rippled through the local agriculture community.

An early project cooperator with significant dairy manure resources accepted the challenge to not apply commercial nitrogen to an alfalfa field that had manure applied at modest rates as determined by project staff assisting with manure spreader calibration and manure testing. The corn yield from the field was the highest in the local ag-coop annual yield contest resulting in considerable community discussion of a high yield with no commercial nitrogen application. This grower had been using 125 pounds of commercial $\mathrm{N}$ on corn following alfalfa. (ISU Extension specialist, 2009)

The farmers with strong conservationist identities recognized that they and the watershed group were helping farmers with strong productivist identities feel comfortable taking some risks. The farmer-led watershed group and small financial incentives provided the encouragement farmers with strong productivist identities needed to activate conservationist identities and incorporate them into their good farmer identity standards. This farmer clearly recognized the reluctance of some of his neighbors to embrace practices that did not meet the informal local crop standards:
It gives them a reason, and I never really looked at it that way, but it probably gives them a reason, where I didn't need a reason. They're [productivist farmers] afraid to have their crop not look as good or look different than it did previously, because there is tons of neighbor pressure, you know. Everybody watches the other guy. They don't go pick corn 'til the other guy goes out. Or they don't do this 'til the other guy. Well, this gives them a reason to try something on their own. It may be a little different than the other guy that's not doing it. (Farmer 2, 2008)

However, over time some farmers with strong productivist identities listened and learned from their peers in the group thereby gaining the confidence to try performancebased management practices on their own farms. In this process they became more confident in moving their conservationist identity higher in their good farmer identity hierarchy. This farmer explains how he responded to questions on why he had not applied fertilizer to one half of a crop field:

"How come you only spread fertilizer on half of that field, and you didn't spread fertilizer on the other half? We noticed when you were out there." And then I explained to them what I did then as a test.

You know what? They all come back and wanted to know what I found out. Every single one of them wanted to know- "How did that turn out? What'd you find out?" Like this year, you know, there was a 24-bushel difference. "Well, we noticed you only spread that upper half and the bottom half you didn't. And you had that piece in there where you didn't put no fertilizer on this year. What was the deal with that?"

And they all watch you now, but, you know, they're all interested in your results, and they want to know how things turned out - was it good, was it bad, made no difference? Because I think we've got a couple neighbors that are always skeptical about testing in the program, but they're still interested in what happens. (Farmer 4, 2008)

During the 2008 interviews Farmer 4 mentioned repeatedly that the support of the other watershed group members had motivated him to implement changes that he would not have adopted otherwise. This demonstrates how Farmer 4 was able to make changes to his good farmer identity. Identity theory helps to explain how individual farmers see themselves as persons, as farmers, and as members of farmers in a group and how productivist and conservationist identities can shift under certain social situations and in turn modify the good farmer identity 
standards. Our data provide evidence that when these individuals received input from the social environment that defined them as polluters they took action (changed their output) to clean up their watershed in order to recreate a match between good farmer identity standards and the meanings in the social situation. It appears that the group formation and the associated "identity work" (Snow and McAdam 2000) required for this group of individuals to come together and take collective action had a significant role in the outcomes.

\section{Impacts of integrating productivist and conservationist identities}

Examination of pre (2005/2006) and post (2009) assessment surveys of three farmer-led performance based watershed groups in the northeastern corner of Iowa (including the NE Iowa watershed case study) reveal other changes in farmer behaviors that suggest that productivist and conservationist identity standards were moving toward congruence. Four areas of change included nitrogen use, manure application, farm nutrient impact on water quality, and farm management practices impact on water quality.

On the issue of nitrogen use, the number of farmers reporting making regular reductions of the amount of nitrogen they applied over the past 5 years, increased from 61 to $76 \%$. By 2009, $57 \%$ of the farmers reported reducing nitrogen application in order to reduce the amount of nitrogen flowing in local groundwater sources. The use of tests to measure the amount of nitrogen in the soil shot up dramatically. In 2004/2005 only 2.8 and $4.3 \%$ of farmers used stalk nitrate tests and late spring nitrogen tests, respectively. In 2009, the percentage of farmers using those tests was 63.3 and $28.2 \%$, respectively. Since these tests were the focus of education and incentives in the watershed groups, it demonstrates how these tools moved from practically no use to substantial use.

Awareness that the byproducts and practices of livestock and crop production have an impact on water quality also increased. In the original surveys about $60 \%$ reported that "some" or "most" of the watershed residents thought there was a water quality problem in their watershed. By 2009 those two categories totaled $92 \%$. As a further confirmation of the influence of the watershed group's impact on beliefs in the three watersheds surveyed, the number of respondents reporting that they knew the goals for their watershed increased from $12 \%$ in the original surveys to just over $38 \%$ in 2009. Farmers' recognition of the potential for nitrogen, phosphates, herbicides, soil erosion, and fecal coliform bacteria to pollute water increased as well. Not only did they recognize the potential of various inputs and outputs of agriculture to cause NPS pollution, the farmers also recognized how their farm practices led to the contamination of water. In 2005/2006 about $53 \%$ of farmers were willing to make changes in farm practices in order to meet local watershed goals; by 2009 it had grown to $67 \%$. Farmers were asked to report which of more than 20 farm management practices they were using to reduce water pollution. In the original surveys the respondents reported heavy use of grass waterways $(75 \%)$, soil testing $(66.7 \%)$, reduced tillage $(64.8 \%)$, nutrient management plans $(61.1 \%)$, and filter strips along water bodies $(50 \%)$. By 2009, the farmers reported using more waterways $(79.1 \%)$, reduced tillage $(83.3 \%)$, and no till $(50 \%)$.

\section{Conclusion}

In the research presented here, the activation of farmers' conservationist identities in a group setting led to a tempering of the profitability self-interest productivist standard and shifted identity standards toward a shared other-interest reflected in the willingness to adopt conservation practices that addressed soil and water vulnerabilities As the pre- and post-survey results attest, there were dramatic changes in what farmers reported thinking and doing related to farm management practices. The final project report provided an overview of changes that occurred through the watershed group:

Over the three years an ownership of the impairment issues, development of remediation efforts and celebration of project successes resulted in leadership development and a very large commitment of watershed residents' time and effort. This development of "watershed community" is a major project outcome that will provide project sustainability. Neighbor-toneighbor exchange of information was identified in the pre-project survey as the most important source of resident information and was very evident and useful to attain participation and dissemination of information. The cooperator in-kind contribution to the project is estimated at $\$ 80,937$ or $21 \%$ of project total cost. (ISU Extension specialist, 2009)

The practice of HIHO agriculture in the United States has resulted in significant negative environmental impacts on US farmlands and water bodies. The challenge is how to reduce the tension and rebalance the relationship between farm-level productivity and collective-level environmental sustainability (Morton et al. in press). Environmental effects can be reduced if farmers adapt their farm management practices to include conservation approaches that reduce the amount of agricultural pollutants that leave their farms through the water system. Our work suggests that the conservation identity needs to be activated and socially 
supported if it is to not be overwhelmed by the economic profit identity standard. Feedback loops among the perceptions of the good farmer role and social identities are mechanisms that may serve as catalyst for shifting farmer behaviors towards conservation management. The performance-based environmental management process used in a watershed group setting has potential to create social situational meanings that could influence farmers to systematically modify their good farmer identities. The connection of farmers to a group seems to facilitate the development of shared watershed goals, something that individual farm operators are often unable to do on their own.

This exploratory research provides a first glimpse at how Iowa farmers using HIHO agricultural practices were motivated to adjust their views of farming to include managing for environmental benefits while achieving strong yields and profits. Continuing research in this area is needed. Farmers are in a unique position to serve as providers of food and fuel and stewards of the planet's freshwater supplies. Although this is a case study of farmers in a unique place and time that is not generalizable to other situations, there are some lessons learned that suggest lines of inquiry that future research might find fruitful. The farmers in this study were quite fearful that they would be subject to regulatory enforcement if the agricultural pollutants were not reduced. The situational context of an impaired watershed and regulatory threat seemed to provide motivation for mobilizing the watershed farmers. We were not able to answer how much of the change occurred because of this "crisis" but regulations may be an important environmental factor in activating the conservationist identity.

Second, many farmers realized that they needed to spend less on synthetic nitrogen fertilizer as they learned to more accurately measure the nitrogen provided by the manure from their small livestock operations. This suggests that farmers may not have a good quantitative assessment of their total nitrogen applications. Nitrogen is one of the most important farm inputs for assuring crop productivity and a major source of water degradation. Thus, decision support tools that provide feedback loops for accurately tracking and evaluating total nitrogen needs could help farmers reaffirm both their productivist and conservationist identities.

Furthermore, in the last year of the study unusually heavy rains caused severe, widespread flooding and soil erosion, demonstrating in a dramatic fashion the benefits of recently installed waterways and buffers. Although, this was a localized experience in a specific year and season, climate scientists are increasingly warning that precipitation and temperatures will become more volatile and farmers are likely to experience extreme events more frequently with significant effects on crops and water quality conditions (Hatfield et al. 2011). This suggests that extreme weather events that affect crop production could be an external feedback influence that triggers a farmer conservationist identity.

As noted earlier, non-farmers in the United States see farmers as disproportionately high users and polluters of water. If farmers do not act to reduce the flow of agricultural pollutants into the country's water system, it is likely that citizens (through their governments) will push for increased regulation of agriculture. Like their peers in the United States, European Union farmers are being pushed to reduce the amount of pesticides, fertilizers, and soil flowing into water ways (European Commission 2012). One of the most widely used artificial nitrogen fertilizers currently used in row crop production is anhydrous ammonia. Since the production of this fertilizer requires large amounts of energy to produce, the cost of this input has more than tripled in cost from 2001 to 2011 (Schnitke 2011). This increase may push farmers to consider more biological sources of fertilizer that may be of lower cost. Finally, the increasing number of extreme weather events and predicted changes in climate will continue to make clear the negative impacts that many farming practices have on soil and water. Because both are needed for humanity to survive, it is likely that farmers will need to adopt new farm management strategies and practices in order to continue producing high yields of food, fuel, and fiber while protecting water quality (Buckland 2004). Social and economic research that guides public policy and farmer practice is needed if we are to find a sustainable balance among food security, earning a living, and the need for a clean environment.

Acknowledgments We would like to thank two anonymous reviewers whose suggestions greatly improved this paper. The first author would like to acknowledge the substantial input provided by the co-authors to the development of the model presented in Fig. 2. This research was funded by the United States Department of Agriculture National Institute for Food and Agriculture (NIFA) under agreement 2008-51130-19526, also known as The Heartland Regional Water Coordination Initiative.

Open Access This article is distributed under the terms of the Creative Commons Attribution License which permits any use, distribution, and reproduction in any medium, provided the original author(s) and the source are credited.

\section{References}

Ajzen, I., and M. Fishbein. 1980. Understanding attitudes and predicting social behavior. Englewood Cliffs, NJ: Prentice Hall.

Arbuckle Jr, J.G., P. Lasley, P. Korsching, and C. Kast. 2009. 2009 Summary report: Iowa farm and rural life poll. Ames, IA: Iowa State University Extension.

Bishop, C.P., C.R. Shumway, and P.R. Wanschneider. 2010. Agent heterogeneity in adoption of anaerobic digestion technology: Integrating economic, diffusion, and behavioral theories. Land Economics 86: 585-608. 
Bohlen, J.M., and G.M. Beal. 1957. The diffusion of process. Special report no. 18. Ames, IA: Agriculture Extension Service, Iowa State University.

Boonstra, W., J. Ahnström, and L. Hallgren. 2011. Swedish farmers talking about nature-A study of the interrelations between farmers' values and the sociocultural notion of naturintresse. Sociologia Ruralis 51: 420-435.

Brasher, P. 2011. Perennial corn holds hope for cutting environmental damage. Des Moines, IA: Des Moines Register. 4 May 2011, A1.

Buckland, J. 2004. Ploughing up the farm: Neoliberalism, modern technology, and the state of the world's farmers. New York: Zed Books.

Burke, P.J. 2006. Identity change. Social Psychology Quarterly 69: 81-96.

Burke, P.J. 2004. Identities and social structures: The 2003 CooleyMead award address. Social Psychology Quarterly 67: 5-15.

Burke, P.J. 1997. An identity model for network exchange. American Sociological Review 62: 134-150.

Burke, P.J. 1991. Identity processes and social stress. American Sociological Review 56: 836-849.

Burke, P.J., and J.E. Stets. 2009. Identity theory. New York: Oxford Press.

Stets, J.E., and P.J. Burke. 2000. Identity theory and social identity theory. Social Psychology Quarterly 63: 224-237.

Burton, R.J.F. 2004. Seeing through the "good farmer's" eyes: Towards developing an understanding of the social symbolic value of "productivist" behavior. Sociologia Ruralis 44: 195-216.

Burton, R.J.F., and U.H. Paragahawewa. 2011. Creating culturally sustainable agri-environmental schemes. Journal of Rural Studies 27: 95-104.

Burton, R.J.F., and G.A. Wilson. 2006. Injecting social psychology theory into conceptualizations of agricultural agency: towards a "post-productivist" farmer self-identity. Journal of Rural Studies 22: 95-115.

Campbell, J., T. Koontz, and J. Bonnell. 2011. Does collaboration promote grass-roots behavior change? Farmer adoption of best management practices in two watersheds. Society \& Natural Resources 24: 1127-1141.

Chouinard, H.H., T. Paterson, P.R. Wandschneider, and A.M. Ohler. 2008. Will farmers trade profits for stewardship? Heterogeneous motivations for farm practice selection. Land Economics 84: 66-82.

Coughenour, C.M. 2003. Innovating conservation agriculture: The case of no-till cropping. Rural Sociology 68: 278-304.

Dobbs, T.L., and J.N. Pretty. 2004. Agri-environmental stewardship schemes and multifunctionality. Review of Agricultural Economics 26: 220-237.

European Commission. 2012. Agriculture and water-Agriculture and rural development. http://ec.europa.eu/agriculture/envir/water/ index_en.htm. Accessed 15 March 2012.

Elworth, L. 2011. Sharing common interests means EPA can work with agriculture. Des Moines, IA: Des Moines Register. 28 October 2011.

Floress, K., L. Prokopy, and S. Allred. 2011. It's who you know: Social capital, social networks, and watershed groups. Society \& Natural Resources 24: 871-886.

Genskow, K. 2012. Taking stock of voluntary nutrient management: Measuring and tracking change. Journal of Soil and Water Conservation 67: 51-58.

Harris, C.K., and C. Bailey. 2002. Public support for a clean, green, US agriculture machine. In The social risks of agriculture: Americans speak out on food, farming, and the environment, ed. R.C. Wimberley, C.K. Harris, J.J. Molnar, and T.J. Tomazic, 31-42. Westport, CT: Praeger.
Hatfield, J.L., K.J. Boote, B.A. Kimball, L.H. Zisha, R.C. Izaurralde, D. Ort, A.M. Thomson, and D. Wolfe. 2011. Climate impacts on agriculture: Implications for crop production. Agronomy Journal 103: 351-370.

Heise, D.R. 1979. Understanding events: Affect and the construction of social action. New York: Syndics of Cambridge University Press.

Herndl, C., J. Goodwin, L. Honeycutt, G. Wilson, S. Graham, and D. Niedergeses. 2011. Talking sustainability: Identification and division in an Iowa community. Journal of Sustainable Agriculture 35: 436-461.

Lemke, A.M., T.T. Lindenbaum, and W.L. Perry. 2010. Effects of outreach on the awareness and adoption of conservation practices by farmers in two agricultural watersheds of the Mackinaw River, Illinois. Journal of Soil and Water Conservation 65: 304-315.

Lockie, S. 1998. Environmental and social risks, and the construction of "best-practice" in Australian agriculture. Agriculture and Human Values 15: 243-252.

Lokhorst, A.M., J. van Dijk, H. Staats, E. van Dijk, and G. de Snoo. 2010. Using tailored information and public commitment to improve the environmental quality of farmlands: An example from the Netherlands. Human Ecology 38: 113-122.

Lynne, G.D. 2006. Toward a dual motive metaeconomic theory. The Journal of Socio-economics 35: 634-651.

Lynne, G.D., and L.R. Rola. 1988. Improving attitude-behavior prediction models and economic variables. Journal of Social Psychology 128: 19-28.

Lynne, G.D., J.S. Shonkwiler, and L.R. Rola. 1988. Attitudes and farmer conservation behavior. American Journal of Agricultural Economics 70: 12-19.

Maybery, D., L. Crase, and C. Gullifer. 2005. Categorizing farming values as economic, conservation, and lifestyle. Journal of Economic Psychology 26: 59-72.

Morton, L.W., G. Miller, J. Rodecap, and S. Brown. 2006. Performance-based environmental management: The Hewitt Creek model. Ames IA: Iowa State University. University Extension Bulletin PM 2013.

Morton, L.W., J. Hobbs, and J.G. Arbuckle Jr. in press. Shifts in farmer uncertainty over time about sustainable farming practices and modern farming's reliance on commercial fertilizers, insecticides, and herbicides. Journal of Soil and Water Conservation.

Morton, L.W., and C.Y. Weng. 2009. Getting to better water quality outcomes: The promise and challenge of the citizen effect. Agriculture and Human Values 26: 83-94.

NRC (National Research Council). 2010. Toward sustainable agricultural systems in the 21st century. Washington, DC: National Academies Press.

NRCS (Natural Resource Conservation Service). 2010. Overview and history of hydrologic units and the watershed boundary dataset (WBD). http://www.ncgc.nrcs.usda.gov/products/datasets/water shed/history.html. Accessed 1 Dec 2010.

Pelkmans, L. 2005. Biofuels in the United States. The European Commission. http://wwwa.vito.be/bioses/pdf/D2a_biofuels_\%20 US_Nov2005.pdf. Accessed 25 Nov 2010.

Pfeffer, M.J., and L.P. Wagenet. 2011. Communities of interest and the negotiation of watershed management. In Pathways for getting to better water quality: The citizen effect, ed. L.W. Morton, and S.B. Brown, 109-120. New York: Springer.

Pretty, J.N. 1995. Regenerating agriculture: Policies and practices for sustainability and self-reliance. Washington, DC: John Henry Press.

Prokopy, L., K. Floress, D. Klotthor-Weinkauf, and A. BaumgartGetz. 2008. Determinants of agricultural best management practice adoption: Evidence from the literature. Journal of Soil and Water Conservation 63: 300-311. 
Reimer, A.P., A.W. Thompson, and L.S. Prokopy. 2012. The multidimensional nature of environmental attitudes among farmers in Indiana: Implications for conservation adoption. Agriculture and Human Values 29: 29-40.

Ribaudo, M. 2011. Reducing agriculture's nitrogen footprint: Are new policy approaches needed? Amber Waves. http://www.ers.usda. gov/AmberWaves/September11/Features/NitrogenFootprint.htm. Accessed 14 Jan 2012

Ribaudo, M., and R. Johansson. 2006. Water quality: Impact of agriculture. In Agricultural resources and environmental indicators, ed. K. Wiebe, and N. Gollehon, 33-41. Washington, DC: US Government Printing Office.

Rogers, E. 1983. Diffusion of innovations. New York: Free Press.

Schneider, F., T. Ledermann, P. Fry, and S. Rist. 2010. Soil conservation in Swiss agriculture-Approaching abstract and symbolic meanings in farmers' life-worlds. Land Use Policy 27: 332-339.

Schnitke, Gary. 2011. Relationship between anhydrous ammonia and natural gas prices. http://www.farmdoc.illinois.edu/manage/ newsletters/fefo11_18/fefo11_18.html. Accessed 18 Mar 2012.

Schulte, L., J. Donahey, L. Gran, T. Isenhart, and J. Tyndall. 2010. People in ecosystems/watershed integration: A dynamic watershed tool for linking agroecosystem outputs to land use and land cover. Journal of Soil and Water Conservation 65: 33A-36A.

Selfa, T., and T.A. Becerra. 2011. Upstream, downstream: Forging a rural-urban partnership for shared water governance in central Kansas. In Pathways for getting to better water quality: The citizen effect, ed. L.W. Morton, and S.B. Brown, 121-132. New York: Springer.

Sheeder, R.J., and G.D. Lynne. 2011. Empathy-conditioned conservation: "Walking in the shoes of others" as a conservation farmer. Land Economics 87: 433-452.

Simon, H.A. 1955. A behavioral model of rational choice. The Quarterly Journal of Economics 69: 99-118.

Sitko, Nicholas. 2007. Maize, food insecurity, and the field of performance in southern Zambia. Agriculture and Human Values 25: $3-11$.

Slovic, P. 2009. The perception of risk. Sterling, VA: Earthscan Publications Ltd.

Snow, D.A., and D. McAdam. 2000. Identity work processes in the context to social movements: Clarifying the identity/movement nexus. In Self, identity, and social movements, ed. S. Stryker, T. Owens, and R. White, 41-67. Minneapolis, MN: University of Minnesota Press.

Stets, J.E. 2006. Identity theory. In Contemporary social psychological theories, ed. P.J. Burke, 88-110. Stanford, CA: Stanford University Press.

Stets, J.E. 1997. Status and identity in marital interaction. Social Psychological Quarterly 60: 185-217.

Stets, J.E., and P.J. Burke. 2003. A sociological approach to self and identity. In Handbook of self and identity, ed. M.R. Leary, and J. Tangney, 128-152. New York: The Guilford Press.
Stets, J.E., and M. Carter. 2011. The moral self: Applying identity theory. Social Psychology Quarterly 74: 192-215.

Stryker, S. 1980. Symbolic interactionism: A social structural version. Menlo Park, CA: The Benjamin/Cummings Publishing Company.

Stryker, S., and P.J. Burke. 2000. Past, present, and future of identity theory. Social Psychology Quarterly 63: 284-297.

Sutherland, L., and R.J.F. Burton. 2011. Good farmers, good neighbors? The role of cultural capital in the social capital development in a Scottish farming community. Sociologia Ruralis 51: 238-255.

Tsushima, T., and P.J. Burke. 1999. Levels, agency, and control in the parent identity. Social Psychology Quarterly 62: 173-189.

US EPA (United States Environmental Protection Agency). 2009. Nitrogen and phosphorus pollution. http://www.epa.gov/nutrient pollution/. Accessed 12 July 2011.

Wilson, G.A. 2004. The Australian Landcare movement: Towards "post-productivist" rural governance? Journal of Rural Studies 20: 461-484.

Wilson, P.F., and R.D. Pearson. 1995. Performance-based assessments: External, internal, and self-assessment tools for total quality management. Milwaukee, WI: ASQC Quality Press.

Wortmann, C.S., A.P. Christiansen, K.L. Glewen, T.A. Hejny, J. Mulliken, J.M. Peterson, D.L. Varner, S. Wortmann, and G.L. Zoubek. 2005. Farmer research: Conventional experiences and guidelines for alternative agriculture and multi-functional agroecosystems. Renewable Agriculture and Food Systems 20: $243-251$.

\section{Author Biographies}

Jean McGuire completed her Master of Rural Sociology at Iowa State University and is currently working on her $\mathrm{PhD}$ in the Department of Sociology at Iowa State University. Her research focuses on human dimensions of natural resource management and farmer decision making from the social psychological view of self and identity.

Lois Wright Morton is a professor of Rural Sociology in the Department of Sociology at Iowa State University. Her research work focuses on civic structure, human dimensions of natural resource management, community based watershed management, farmer decision making, and rural quality of life.

Alicia D. Cast is an associate professor of Sociology in the Department of Sociology at University of California-Santa Barbara. Her primary research interests include social psychology, family, and gender. Her work focuses on issues related to self and identity in family relationships. 